
\title{
Systems
}

\section{Performance Evaluation of a Solar PV/T Water Heater Integrated with Inorganic Salt Based Energy Storage Medium}

\author{
Prakash $\mathrm{R}^{1, *}$, Meenakshipriya $\mathrm{B}^{2}$, Vijayan $\mathrm{S}^{3}$ and Kumaravelan $\mathrm{R}^{1}$ \\ ${ }^{1}$ Department of Mechanical Engineering, Velalar College of Engineering and Technology, Thindal, Erode 638012, Tamilnadu, \\ India \\ ${ }^{2}$ Department of Mechatronics Engineering, Kongu Engineering College, Perundurai, Erode 638052, Tamilnadu, India \\ ${ }^{3}$ Department of Mechanical Engineering, National Institute of Technology, Tiruchirappalli, 620015, Tamilnadu, India
}

\section{Corresponding Author Email: rprakashenergy@gmail.com}

\begin{abstract}
Thermal and Electrical performance of solar PV/T hybrid water heating system using salt mixture phase change materials in storage tank is analyzed in this study. Compare to all conventional type heaters, the solar PV/T hybrid module collector has ability to produces both electrical energy from PV module and utilizes incident solar energy to heat the water. The sheet and tube type absorber is used to heat up the tube which is attached at the back side of PV module and transfer the heat to flowing water and the electrical energy is tested by connecting the DC load on the PV terminals under glazed and unglazed modes respectively. To enhance the thermal performance, energy storage medium is used as phase change materials at good proportion in the tank. The thermo physical properties of PCM are analyzed by Differential Scanning Calorimetry. This experimental testing is conducted from 8.00 to 17.00 IST in various sunny days and results are compared for glazed and unglazed conditions. The results shows that the average water temperature easily reaches $38-45^{\circ} \mathrm{C}$ and the final temperature of water never dropped below $34^{\circ}$, the temperature of PCM is $45.60 \mathrm{C}$, which is $5 \mathrm{oC}$ higher than outlet. The amount of heat stored using PCM in tank is $16.86 \%$ greater than no-PCM in the tank for constant $0.01 \mathrm{~kg} / \mathrm{s}$ mass flow rate. The daily average electrical efficiency is $6.4 \%$ under glazed mode and $8.8 \%$ under unglazed conditions.
\end{abstract}

Keywords: PV/T hybrid module, phase change materials, salt mixture, differential scanning calorimetry Received: July-20-2020, Accepted: July-26-2020, https://doi.org/10.14447/jnmes.v23i3.a09

\section{INTRODUCTION}

Energy offers a remarkable contribution in improving the life standard of human beings. Major part of the energy requirements for the domestic and industrial applications are met with fossil fuels. Unfortunately, the sole dependency of the fossil fuels has led to unimaginable rise in price and threatening environmental pollution. Nowadays, renewable energy sources are being emphasized to address the aforementioned problems. Solar energy seems to be the promising choice as it is clean and freely available everywhere. Solar thermal energy from sunlight is used to heat water or other fluids, and can also power solar cooling system applications. Numerous thermal management technologies in $\mathrm{PV} / \mathrm{T}$ are explored, and various specifications with performance enhancement techniques were incorporated in the $\mathrm{PV} / \mathrm{T}$ collectors. Generally, they are subdivided further into air-heating $\mathrm{PV} / \mathrm{T}$ and water-heating $\mathrm{PV} / \mathrm{T}$ based on the variance (medium of heat transfer) involved in the process. In the solar PV/T hybrid module, both electrical and thermal energy are extracted. Approximately, $75 \%$ of solar radiation falling on a surface is reflected as loss or absorbed as heat sources. Thermal management in solar photovoltaic panel is considered for improving the electrical performance of the module and the PV module cooling with a fluid stream like air or water, the electricity yield can be improved. At the same time, the heat pick-up from the fluid can be used to support domestic or residential hot-water systems.

Recent researchers have suggested that the incorporation of phase change materials (PCM) is also a favourable option to improve the performance $\mathrm{PV} / \mathrm{T}$ collectors. PCMs are incorporated in the solar thermal water tank to withhold the thermal energy in the form of sensible and latent heat. He et al. [1] studied the thermal performance of solar flat-box type hybrid solar collector using aluminum-alloy and achieved $40 \%$ on daily basis. Khalifa et al. [2] designed the solar collector using paraffin wax as phase change materials in the copper pipes of diameter $80 \mathrm{~mm}$. By the use of PCMs in the storage media will enhance the heat transfer performance even at no sunlight and acts as the heat source in the late evenings. Mosaffa et al. [3] tested the multiple PCMs rather than single PCM in the latent heat storage system. It was found that the heat transfer performance shows greater improvement using metal fins kept inside metal screens and beads and impregnation on the porous materials. Allan et al. [4] experimented serpentine type solar collector and found that the overall efficiency is $61 \%$ higher and electrical efficiency is $8 \%$ lower than other system. Preet et al. [5] experimented the water based solar PV/T collector using paraffin wax as phase change material and investigated the effect of mass flow rate. They found that the thermal efficiency of the system increases with increase in flow rate of water. Al-Waeli et al. [6] reviewed the various techniques and methods used in solar 
$\mathrm{PV} / \mathrm{T}$ system for enhancing the thermal and electrical efficiency using phase change materials. It has shown more interest in research to increase the productivity and in by reducing the cost. Yang et al. [7] conducted daily tests for comparing the performance of $\mathrm{PV} / \mathrm{T}$ system and $\mathrm{PV} / \mathrm{T}$ system with PCM. The result found that thermal and electrical efficiency by using PCM will be improved compared to conventional system and the simulation analysis are also checked using TRNSYS. Smyth et al. [8] designed a new type solar PV/T integrated facade collector system and tested at indoor solar simulator conditions. The efficiency of the new system is $5-10 \%$ better than a traditional unglazed hybrid system and calculated the heat retention efficiency for single and double-glazed condition. Browne et al. [9] tested the hybrid PV/T solar heater at three different condition $\mathrm{PV} / \mathrm{T}$ system with PCM called Capric:Palmitic acid, PV/T system without PCM and PV module alone. The results show that by using PCM in the hybrid system, it can store more heat compared to traditional one. Browne et al. [10] discussed the various types of solar collector by adopting phase change materials at varying environment. In all types, the performance will be improved by using PCM. Venkatesh and Vijayan [11] designed and analysed the performance of the multi-purpose solar water heater. Iserval et al. [12] and kumar et al. [13], solar collectors for heating water. Stritih and Stritih [14] modified the solar PV system using phase change materials RT28HC and found that the maximum temperature of the panel is $35.6^{\circ} \mathrm{C}$ higher than without using PCM and the same is also simulated using TRNSYS software and validated the results. Browne et al. [15] experimented the PCM called fatty acid eutectic, capric-palmitic in the solar hybrid system and showed that the performance is improved than without using PCM. Browne et al. [16] investigated the application of phase change materials for the thermal performance improvement. The temperature is about $50^{\circ} \mathrm{C}$ regulated using PCM. Zhou and Eames [17] examined the thermal properties of inorganic salts like lithium nitrate and sodium chloride as PCMs. The DSC results proved that the thermal conductivity was $0.56-0.6$ $\mathrm{W} / \mathrm{mk}$. The above salts were tested in three various materials like copper and stainless steel 304 and 316 grade for indirect thermal storage applications. In stainless steel 316 grade, the overall thermal performance is better compared to others.

The literature review revealed that the $\mathrm{PV} / \mathrm{T}$ solar water heating system has many advantageous features and the incorporation of energy storage materials enhance the thermal as well as electrical performance. In an open literature survey, it is noticed that the effect of inorganic salt hydrates as PCM on solar PV/T water heating system performance has not been explored much. Therefore, in this work an attempt is made to study the thermal and electrical performance under glazed and unglazed conditions.

\section{MATERIALS AND METHODS}

\subsection{Experimental Setup Description}

The block diagram of solar PV/T hybrid water heating system is shown in Figure 1. The hybrid PVT module is set by connecting a sheet and tube absorber at the backside of PV module. $20 \mathrm{Wp}$ poly crystalline type module is used in this experiment. The copper sheet of $36 \mathrm{SWG}$ is used as fin and it is painted with black to enhance the solar insolation absorptivity. Copper tube having diameter of $12.7 \mathrm{~mm}$ is used as header and $6.35 \mathrm{~mm}$ copper tubes are used as risers. The centre to centre spacing between the risers is kept as $50 \mathrm{~mm}$. The useful surface area in hybrid module for heat absorption is $0.18 \mathrm{~m}^{2}$ and total PV module cell area is $0.135 \mathrm{~m}^{2}$. To prevent convective heat loss to the ambient, insulation material - glass wool of $25 \mathrm{~mm}$ thickness is used in rear portions of $\mathrm{PV} / \mathrm{T}$ module and total setup is enclosed in a metallic container. The additional glazing is given at the top of the metal box using glass (solar grade sheet) of thickness $4 \mathrm{~mm}$. This module is also made vapor tight using rubber beading. The photograph of the experimental setup is shown in below Figure 2. The PV/T hybrid module is inclined towards south facing and twisted at an angle of $30^{\circ}$ to the ground.

The storage tank is made up of a double shell arrangement in cylindrical shape using SS304 grade sheet. It is enclosed by glass wool material at inner and outer of the tank to reduce heat loss to the environment. The storage collector of 50 litres capacity is used. The tank was fixed at 3 feet elevation from the floor on a metallic stand to ensure the proper circulation of the water through the system. Two numbers of thermometers are used to measure the temperature deviation at various sections such as the centre and the outlet of the storage tank. The heat energy loss to atmosphere is minimized by using the rubber beading at the outer surface of the tubes and the arrangement of PCM aluminium canisters in rack are shown in Figure 3.

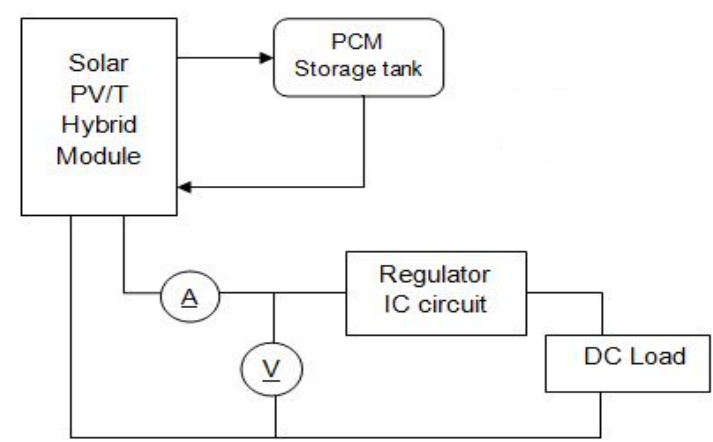

Figure 1. Block diagram of solar PV/T hybrid water heater



Figure 2. Experimental setup 




Figure 3. PCM containers

\subsection{Phase Change Materials (PCMs)}

The two inorganic salts hydrates like sodium thiosulphate pentahydrate $\left(\mathrm{Na}_{2} \mathrm{SO}_{3} .5 \mathrm{H}_{2} \mathrm{O}\right)$ and magnesium nitrate hexahydrate $\left(\mathrm{Mg}\left(\mathrm{NO}_{3}\right)_{2} \cdot 6 \mathrm{H}_{2} \mathrm{O}\right)$ is selected based on the literature study. The purchased salts from the manufacture are used directly without any purification. The salt mixtures are taken in the proportion $80 \%$ of $\mathrm{Mg}\left(\mathrm{NO}_{3}\right)_{2} \cdot 6 \mathrm{H}_{2} \mathrm{O}+20 \%$ of $\mathrm{Na}_{2} \mathrm{SO}_{3} .5 \mathrm{H}_{2} \mathrm{O}$ in the study. For the experiment, $2.5 \mathrm{~kg}$ of salt mixture PCM is used. During preparation, the two salts were physically mixed and then treated under hot air oven above $100^{\circ} \mathrm{C}$. During the heat treatment, the salt mixture should undergo the heating process above melting range, and converts into a liquid solution. Then the solution was stirred at a speed of $450 \mathrm{rpm}$ for $30 \mathrm{~min}$ with the help of stirrer. Then the hot liquid was allowed to solidify in room temperature in a closed container to prevent unwanted chemical reactions with the ambient air. Due to this, the two different salts are completely mixed with each other and it becomes homogeneous. Finally, by using the agate mortar, the salt mixture solid is altered into powder form. The complete preparation process of $20 \mathrm{gm}$ salt mixture PCM is given in Figure 4.

Differential Scanning Calorimetry (DSC) is used for the evaluating the thermophysical properties like phase transition temperature, latent heat energy and heat stored capacity of PCM after the complete test runs. This testing facility is available at CSIR-CLRI Chennai, Tamilnadu, India. During testing, a small amount of prepared salt $10 \mathrm{gm}$ is used for analysis. After the completion of test runs, DSC provides thermal properties of PCM. The photography of the DSC apparatus during testing is shown in Figure 5. The DSC results of the salt mixture are given in Table 1. PCMs salt was packed into aluminium canisters to avoid heat loss during higher temperature and arranged inside the storage tank.

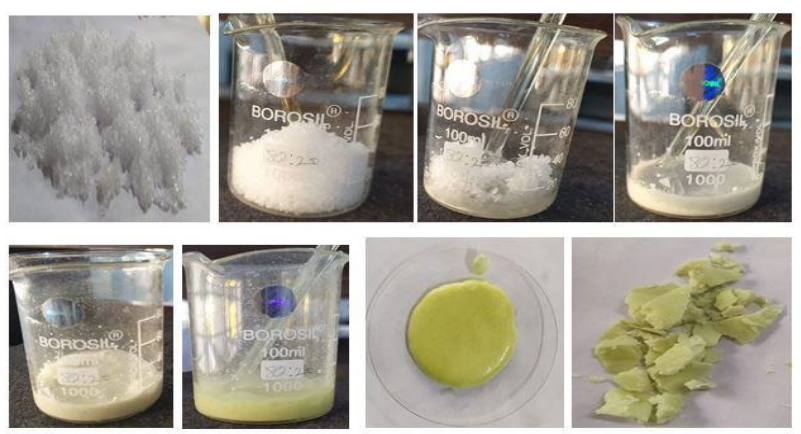

Figure 4. Melting Process of 80:20 salt mixture PCMs

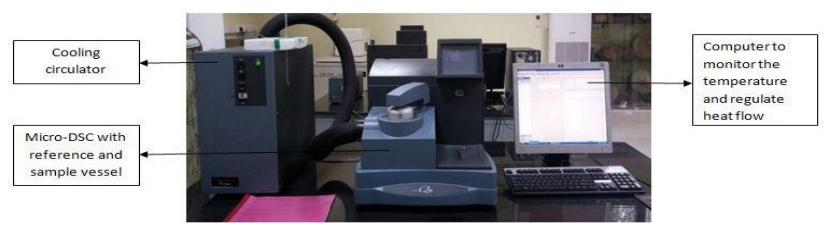

Figure 5. DSC apparatus during sample testing

Table 1. Thermo physical properties of salt PCM at 80:20 mixtures during DSC test

\begin{tabular}{ccc}
\hline S.No & Property & Value \\
\hline. & Phase transition & $34.2^{\circ} \mathrm{C}-$ \\
1. & temperature & $47.3^{\circ} \mathrm{C}$ \\
2. & Latent heat energy & $169.91 \mathrm{~kJ} / \mathrm{kg}$ \\
3. & Heat storage capacity & $15.95 \mathrm{~kJ} / \mathrm{kgK}$ \\
\hline
\end{tabular}

\subsection{Instrumentation and Experimentation Procedure}

The fabricated experimental setup is placed at Erode District ( $\left.11^{\circ} 34^{\prime} \mathrm{N}, 77^{\circ} 71^{\prime} \mathrm{E}\right)$, Tamilnadu, India during testing. The experimental studies are conducted during the month of November 2019 from 08:00 hrs to 17:00 hrs every day. During the experimental testing, the data recordings are done manually by using the instruments such as solar power meter, bulb type thermometer, K-type thermocouple, digital thermometer, multimeter and flowmeter after accurate calibration. A solar power meter is utilized to measure the incident solar radiation at experiment site. The daily measured solar radiations are compared with the data's available in the Tamilnadu Meteorological Weather Report. The bulb thermometers are used to measure the tank temperature at various positions. To measure the ambient air temperature, Ktype thermocouple is used. In order to record the temperature of $\mathrm{PV} / \mathrm{T}$ module, module temperature is measured by using digital thermometer. Two digital multimeters are connected across the PV panel output terminals to know the varying voltage and current during the glazed and unglazed conditions. The flowmeter is used to measure the mass flow rates of water. The inlet water to the storage tank was collected from an overhead water tank which is at 6 feet from the ground. The water from the tank flows into the hybrid module gets heated and rises to the tank again. Based on thermosyphon principle, the hot water increases due to lower density. The parameters like water temperature (at inlet, at outlet, on PCM container), ambient temperature, module temperature on top \& bottom, tank temperature, voltage and current across the PV module are noted. By the measured quantities, the thermal, electrical and primary energy saving efficiencies are analyzed.

\section{DATA REDUCTION}

The experimental setup is tested on daily basis from morning 8 am to evening $5 \mathrm{pm}$ and the variation of the water temperature is recorded at a periodic interval. The electrical performance of solar photovoltaic like power, voltage and current production is noted at every 30 minutes time duration and the average results are used for analysis.

The thermal efficiency of the water heater fully depends on solar isolation, ambient temperature, wind speed etc. The formula used to calculate $\eta_{t h}$ is: 


$$
\eta_{t h}=\frac{m \times C_{p} \times\left(T_{f}-T_{i n}\right)}{H \times A_{c}}
$$

where, $\mathrm{m}$ is the mass of water used in $\mathrm{kg}, C_{p}$ is the specific heat of water in $\mathrm{J} / \mathrm{kgK}, \mathrm{H}$ be the overall solar isolation on the collector surface in $\mathrm{W} / \mathrm{m}^{2}, T_{\text {in }}$ and $T_{f}$ are the initial and final water temperatures in $\mathrm{K}$ and $\mathrm{A}_{\mathrm{c}}$ is the collector surface area in $\mathrm{m}^{2}$.

The formula used to calculate the thermal performance of the system; when the solar absorptance $(\alpha)$, overall system loss coefficient $(\mathrm{U})$ and the average ambient temperature $\left(T_{a m b}\right)$ are known:

$$
\eta_{t h}=\alpha+U \times\left(\frac{T_{i}-T_{a m b}}{H}\right)
$$

The daily electrical efficiency $\eta_{e l}$ is calculated using the below equation,

$$
\eta_{e l}=\int_{\text {day }}\left(\frac{V_{L} \times I_{L}}{A_{p v} \times H}\right)
$$

where $V_{L}, I_{L}, A_{p v}$ are load voltage, load current and radiation collecting area of the PV module respectively. In this expression, $\mathrm{H}$ value should be taken in the unit $\mathrm{kWh} / \mathrm{m}^{2}$.

\section{RESULTS AND DISCUSSION}

Experimental results of hybrid PV/T module under various conditions such as glazed and unglazed, with and without using PCM in storage tank have been reported and discussed. The thermal and electrical performances of the system and temperature variation on the $\mathrm{PV} / \mathrm{T}$ module have been analyzed in the present section.

\subsection{Variation of temperature of $\mathrm{PV} / \mathrm{T}$ module with solar radiation}

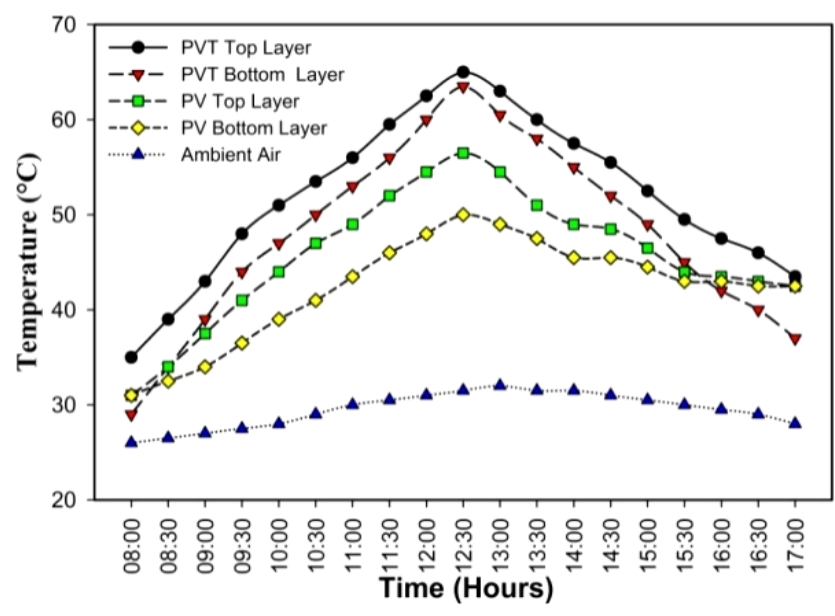

Figure 6. Temperature profile during load test

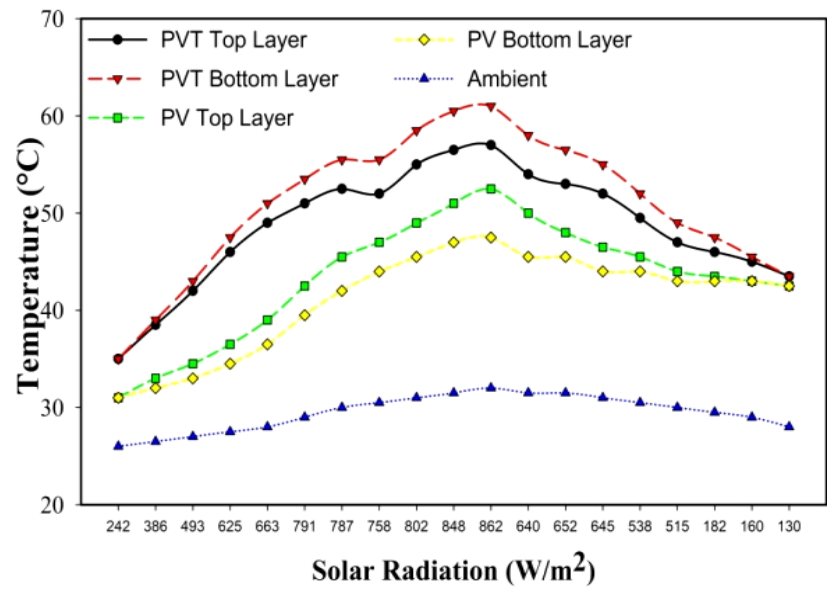

Figure 7. Temperature profile during no-load test

The outlet water temperature during load and no-load test on time variation are shown in Figures 6 and 7. The load test is carried out by connecting the electrical terminals of the hybrid module. In this case, both thermal and electrical energy is produced simultaneously. The temperature on PV and PV/T module are measured separately on the same site location and at variation positions like $\mathrm{PV} / \mathrm{T}$ top \& bottom, PV top \& bottom and ambient are analyzed. From Figure 6, it is observed that the higher temperature is at PV/T top because of combined power generation during PV process and reelected radiation within the module and followed by $\mathrm{PV} / \mathrm{T}$ bottom due to blocking of incoming solar radiation by copper. Next higher temperature is at PV top and bottom, because the transparency in copper sheet is always higher than tedlar sheet. The maximum temperature differences of $7.34^{\circ} \mathrm{C}$ and $6.28^{\circ} \mathrm{C}$ between top and bottom layers on PV and PV/T module are noted respectively. The temperature difference between the top and bottom layer is minimum during peak solar energy compared to the PV module. This is because of lower thermal resistance of the $\mathrm{PV} / \mathrm{T}$ module and higher thermal conductivity. During the no-load test, an electrical terminal of PV module is disconnected. Hence, it acts in open-circuit condition; no current will be produced, only as heat energy is generated. Due to isolated conditions of electrical terminals, $\mathrm{PV} / \mathrm{T}$ bottom has higher temperature compared to PV/T top. Since there will be some emission of radiation in copper sheet, it stands second. The peak temperature variation between the top and bottom layers in $\mathrm{PV}$ and $\mathrm{PV} / \mathrm{T}$ module is $5.20^{\circ} \mathrm{C}$ and $4.72^{\circ} \mathrm{C}$. It is found that, $\mathrm{PV}$ and $\mathrm{PV} / \mathrm{T}$ module temperature rise is constant and slightly higher in PV module because of greater thermal resistance.

\subsection{Thermal performance of storage tank with PCMs}

The temperatures of the water storage tank at various location of the tank such as top, middle and bottom portions are measured. Figure 8 shows the measurement of temperature for every 10 minutes time period without any hot water removal. The temperature reached the maximum of $69^{\circ} \mathrm{C}$, $61^{\circ} \mathrm{C}$ and $55^{\circ} \mathrm{C}$ for the tank top, tank middle and tank bottom locations respectively, in one day. The top layer and middle layer of the thermal storage tank showed a steep increase in the temperature build-up, but the tank bottom layer temperature change was more gradual. This provides cooler water to the inlet of the solar collector at bottom. This results in the improved conversion efficiency of the PV/T module. 
From Figure 9, it is seen that the average temperature difference of $4.28^{\circ} \mathrm{C}$ was obtained during the period from $10: 30$ am to $01: 00 \mathrm{pm}$, with a maximum temperature difference of $8.46^{\circ} \mathrm{C}$ between the outlet fluid and inlet fluid of the solar collector. The maximum temperature in PCM container is $54.5^{\circ} \mathrm{C}$, which is $10.77 \%$ higher than the outlet water temperature without PCM. Among all the positions of the tank, PCM container holds higher temperature. This type of PCM has an ability to store the latent heat.

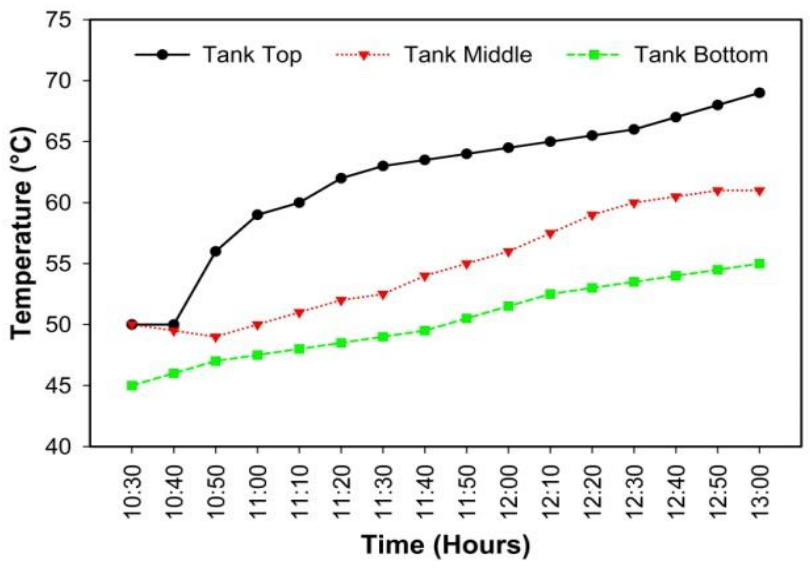

Figure 8. Storage tank temperature performance



Figure 9. Temperature of tank at various positions

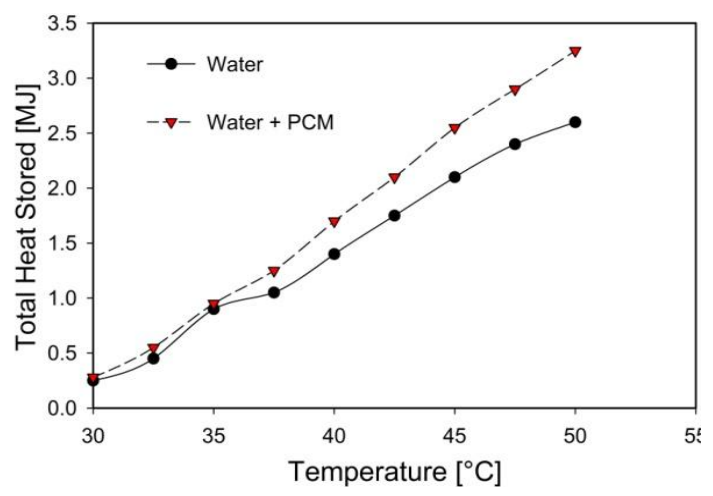

Figure 10. Heat stored performance

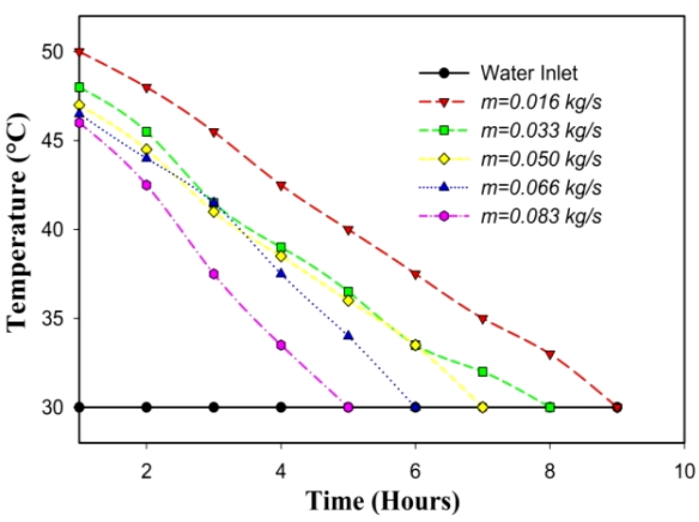

Figure 11. Effect of mass flow rate on temperature

Figure 10 shows the heat stored performance of tank with PCM. A significant improvement of $16.86 \%$ of amount of heat energy stored at same climatic condition. This clearly proved that, by the use of PCM in the tank the heat stored and storage time of heat energy has been increased. So, this type of salt PCM will be highly recommended for the use of heat energy during half sunshine hours. The performance of the hybrid water heater is analyzed by varying the flow rates from 0.01 $\mathrm{kg} / \mathrm{s}$ to $0.0667 \mathrm{~kg} / \mathrm{s}$ as shown in Figure 11. The maximum temperature of the water in the tank was attained at lower mass flow rate of $0.016 \mathrm{~kg} / \mathrm{s}$ and the time taken to attain the stratified temperature of $50^{\circ} \mathrm{C}$ was 9 hours, whereas for $0.016 \mathrm{~kg} / \mathrm{s}$ the time taken to attain the stratified temperature was 5 hours. It clearly depicts that the amount of heat transferred increases with increase in mass flow rate of water. Further, it leads to reduction in reduced stratified temperature in the tank. It revealed that by the addition of PCM in the tank shows better improvement in results. The thermal efficiency of the collector increases with the increase in the rate of water flow, whereas the average temperature rise falls with the rise in the mass flow rate. From the above results, it has been noted that the incorporation of inorganic salt hydrates inside the storage tank has significant effect on the performance by lowering the water temperature to the collector. Hence further experimental studies to investigate the performance under glazed and unglazed conditions. Throughout the studies mass flow rate has been maintained as $0.01 \mathrm{~kg} / \mathrm{s}$.

\subsection{Thermal performance of PV/T module with PCMs}

The semi-empirical system efficiency model that correlates the daily efficiency test results with reduced temperature $\left(T_{i}-\right.$ $\left.T_{a m b}\right) / \mathrm{H}$ are calculated from the equation (2). In this equation, $\alpha$ represents the system efficiency, when $T_{i}=T_{a m b}$. The values of $\alpha$ and $U$ can be determined by linear regression analysis, which has been used in this experimentation. The plots of $\eta_{\text {th }}$ against reduced temperature $\left(T_{i}-T_{a m b}\right) / \mathrm{H}$, for both glazed and unglazed modes, are given in Figure12. The corresponding linear regression line equations were found to be,

For glazed mode $\eta_{t h}=30.01-9.142\left(\mathrm{~T}_{\mathrm{i}}-\mathrm{T}_{\mathrm{amb}}\right) / \mathrm{H}$

For unglazed mode $\eta_{\mathrm{th}}=16.36-15.09\left(\mathrm{~T}_{\mathrm{i}}-\mathrm{T}_{\mathrm{amb}}\right) / \mathrm{H}$

The ' $\alpha$ ' value was found to be lower than a conventional solar thermal collector for both the modes. This is because, the PV module is fixed over the thermal absorber sheet and it 
resists the falling solar radiation on the absorber. The emissivity of a PV module is much higher compared to the absorber of the traditional solar collector which has a selective absorptive layer coated on it. Hence, the heat loss between $\mathrm{PV} / \mathrm{T}$ collector and environment is much higher than that of the traditional solar collector and the absorbed solar energy by the $\mathrm{PV} / \mathrm{T}$ collector is much less than the traditional solar collector. The additional thermal resistance exists between the $\mathrm{PV} / \mathrm{T}$ surface exposed to solar radiation and water path in tube due to aluminium absorber plate and an adhesive layer.
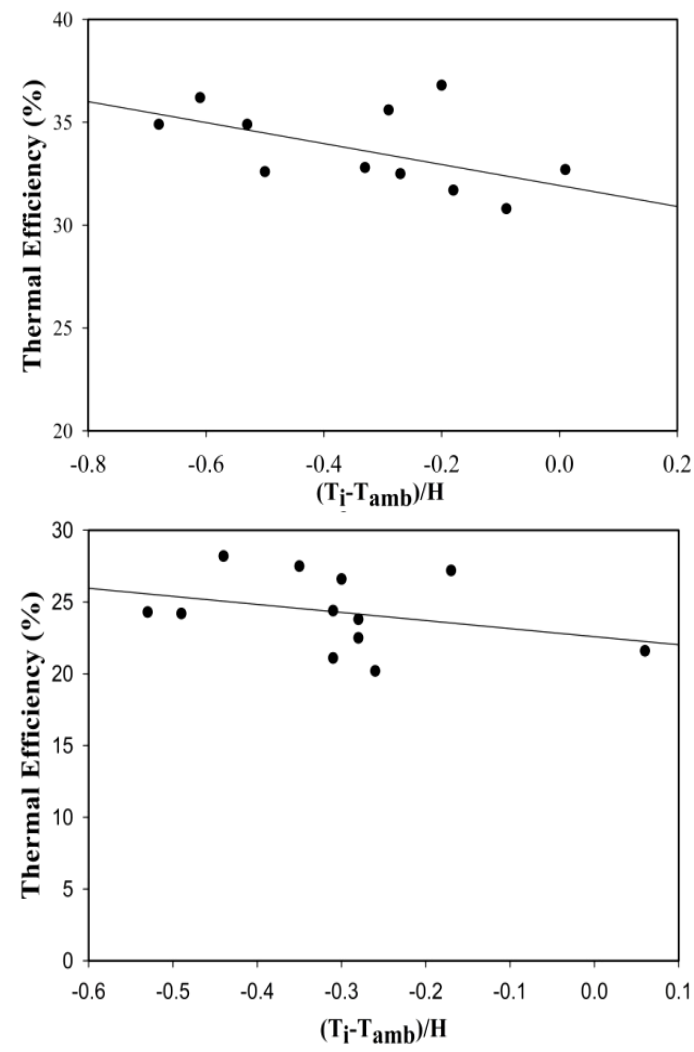

Figure 12. Thermal efficiency vs reduced temperature during glazed and unglazed conditions



Figure 13. Hourly variations in water temperature in glazed and unglazed conditions

The hourly variations in the water temperature for glazed and unglazed modes are shown in Figure 13. The peak water temperature during glazed and unglazed modes is $60^{\circ} \mathrm{C}$ and $50^{\circ} \mathrm{C}$ respectively. There will be $10^{\circ} \mathrm{C}$ temperature rise in glazed compared to unglazed operation. This is because; the extra glazing will reduce the heat loss and in turn increases the
$\mathrm{PV} / \mathrm{T}$ module temperature. It is also found that the water temperature increased till 14:30 hrs after which there was only a marginal rise in it. It showed that the active heating took place between 10:30 hrs to 14:30 hrs during which much of the heating had occurred.

\subsection{Electrical performance of PV/T module with PCMs}

The $12 \mathrm{~V}$ DC bulb is used as electrical load. Two digital multimeters are used for measuring the voltage, current and power of the system. The electrical power is calculated by using the formula $\mathrm{P}=\mathrm{V} \times \mathrm{I}$, whereas the voltage and current are measured from hybrid module. This PV/T hybrid module is tested on both glazed and unglazed conditions separately. The hourly electrical performances of a solar PV/T module have been noted on vary with the solar radiation and shown in Figures 14 and 15. The instant maximum electrical efficiency is achieved at $9.14 \%$ for glazed and $11.94 \%$ for unglazed modes. The average electrical efficiency is $6.4 \%$ and $8.8 \%$ during glazed and unglazed operations. It also found that the daily average electrical efficiency is always smaller than the instantaneous range. In the unglazed modes, more amount of output power is observed compared to glazed modes. In case of glazing modes, due to glazing effect, there will be more reflection losses and hence produces lesser power output and efficiency.

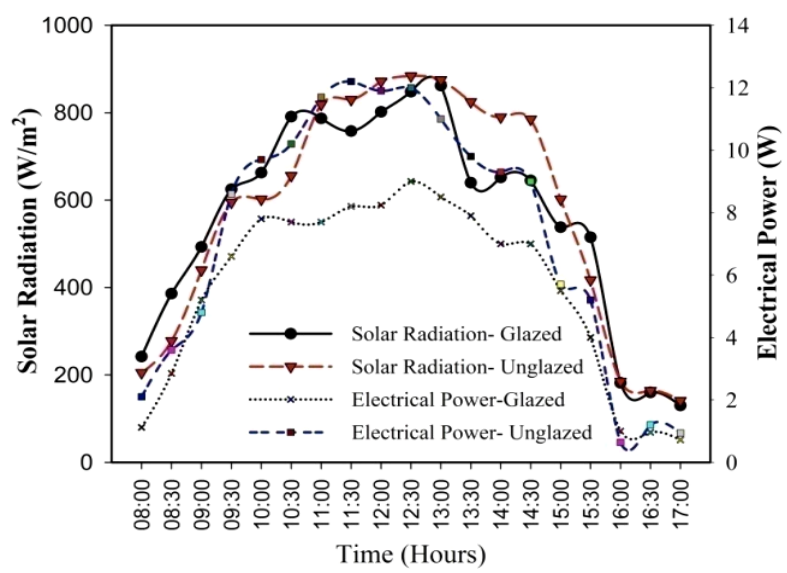

Figure 14. Electrical Power output with solar radiation

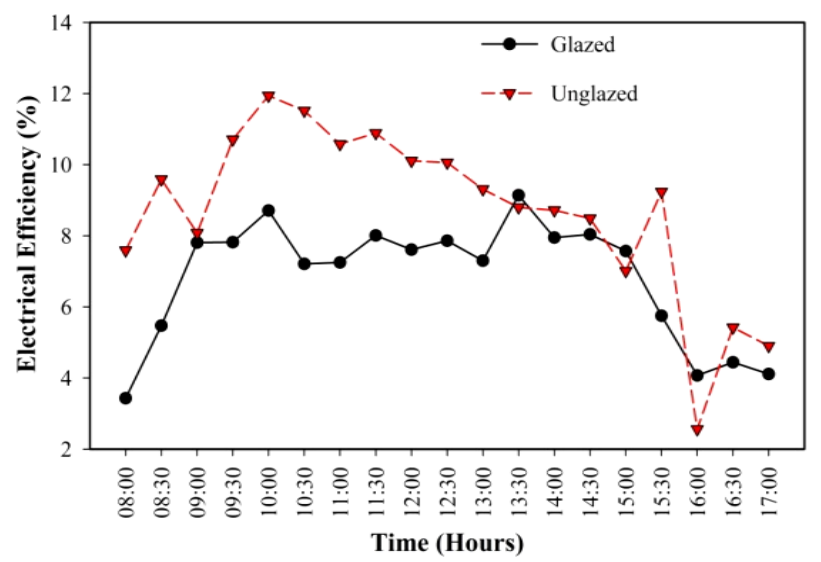

Figure 15. Electrical Efficiency of PV module 




Figure 16. Load voltage vs Time

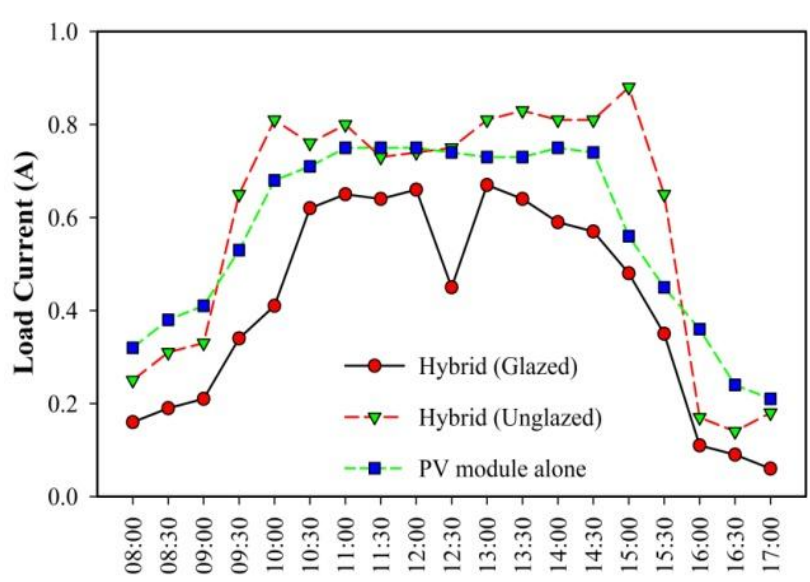

Time (Hours)

Figure 17. Load current vs Time

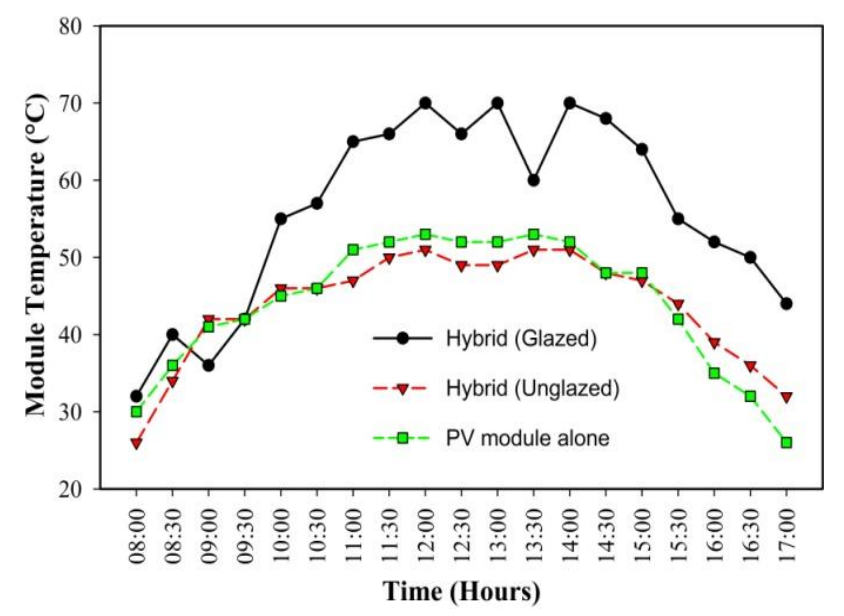

Figure 18. Module temperature vs Time

The electrical efficiency of the PV module is compared with $\mathrm{PV} / \mathrm{T}$ hybrid collector and the results are analyzed. The PV module temperature load voltage and load current at different operating modes such as glazed, unglazed and PV alone are measured and shown in Figure 16, 17 and 18.

The results found that the electrical efficiency of the PV module is $8.1 \%$. It is observed that the solar PV module temperature will easily attain $53^{\circ} \mathrm{C}$ under free convection. The electrical efficiency of the solar hybrid PV/T module should be higher than the PV module; because of the flowing water through the pipes removes the heat directly from the PV module and consequently the temperature of PV module decreases and therefore efficiency will be increased. When there is a good thermal insulation between the PV module and the absorber plate, the water flows through the pipes will increase the heat dissipation from the PV module, and hence heat convection between the PV module and the ambient air will be decreased roughly. In such case, the electrical efficiency is found to be lesser. When the temperature of the flowing water is colder, then the heat transfer between the module and water is increased. In such case, the temperature of the water is increased slowly. Hence, the temperature of PV module in the PV/T hybrid module will be superior to the temperature of a PV module alone. Thus, the electrical performance of hybrid PV/T collector is cheaper. For this reason, the extra glazing cover is required in need of higher power output and efficiency.

\section{CONCLUSIONS}

The performance of the solar PV/T water heating system is continuously improved by using various technologies. One such improvement is by using inorganic salt hydrate as PCM. The thermal performance of the hybrid heater is improved by using PCM in storage tank and also the electrical efficiency of the PV module is improved by using refractive mirror. From experimental results, the following conclusions are made:

- $\mathrm{Mg}\left(\mathrm{NO}_{3}\right)_{2} \cdot 6 \mathrm{H}_{2} \mathrm{O}+\mathrm{Na}_{2} \mathrm{SO}_{3} .5 \mathrm{H}_{2} \mathrm{O}$ salts with $80: 20$ percentage volume fraction has increased the storage tank useful temperature by $16.86 \%$ in thermosyphon mode.

- The maximum practical water temperature in storage tank reached is $75.2^{\circ} \mathrm{C}$.

- The highest outlet temperature from the collector is $75^{\circ} \mathrm{C}$ using salt mixture as PCM in thermosyphon, while the lowest temperature is at $41.6^{\circ} \mathrm{C}$ in $0.01 \mathrm{~kg} / \mathrm{s}$.

- During load test, the maximum temperature difference is $7.34^{\circ} \mathrm{C}$ and $6.28^{\circ} \mathrm{C}$ and in no-load condition, it is $5.1^{\circ} \mathrm{C}$ and $3.8^{\circ} \mathrm{C}$ between top and bottom layers on $\mathrm{PV}$ and $\mathrm{PV} / \mathrm{T}$ module

- The average thermal efficiency using salt mixture PCM is $33.5 \%$ in $0.01 \mathrm{~kg} / \mathrm{s}$

- The average electrical power output is $11.5 \mathrm{~W}$ in $\mathrm{PV} / \mathrm{T}$ module and $11.7 \mathrm{~W}$ in PV module respectively. Hence, the electrical output of the PV/T is alike as PV module.

- The maximum electrical efficiency of the PV/T module is $7.8 \%$ almost same as $8 \%$ in PV module in normal conditions.

- The average daily electrical efficiency of the glazed system is observed at $6.4 \%$ and $8.8 \%$ for unglazed modes with PCM.

- A significant thermal efficiency of $33.25 \%$ improvement is observed with glazing for $0.01 \mathrm{~kg} / \mathrm{s}$, which is $4 \%$ greater than without glazing using PCM.

- The electrical efficiency is reduced as $15.78 \%$ in the presence of glazing with PCM.

In order to increase the yield of electrical performance, the use of automatic tracking controller at the proper tuning circuit is preferable. This is the future scope of the present work. By using salt mixture PCMs, the result shows a greater improvement in the overall thermal performance of the hybrid module and so it is highly suitable for domestic hot water applications. 


\section{REFERENCES}

[1] He, W., Chow, T.T., Ji, J., Lu, J., Pei, G., Chan, L.S. (2006). Hybrid photovoltaic and thermal solar-collector designed for natural circulation of water. Applied energy, 83(3): $199-210$ https://doi.org/10.1016/j.apenergy.2005.02.007

[2] Khalifa, A.J.N., Suffer, K.H., Mahmoud, M.S. (2013). A storage domestic solar hot water system with a back layer of phase change material. Experimental Thermal and Fluid Science, 44: 174-181. https://doi.org/10.1016/j.expthermflusci.2012.05.017

[3] Mosaffa, A.H., Ferreira, C.I., Rosen, M.A., Talati, F. (2013). Thermal performance optimization of free cooling systems using enhanced latent heat thermal storage unit. Applied thermal engineering, 59(1-2): 473479.

https://doi.org/10.1016/j.applthermaleng.2013.06.011

[4] Allan, J., Dehouche, Z., Stankovic, S., Mauricette, L. (2015). Performance testing of thermal and photovoltaic thermal solar collectors. Energy Science \& Engineering, 3(4): 310-326. https://doi.org/10.1002/ese3.75

[5] Preet, S., Bhushan, B., Mahajan, T. (2017). Experimental investigation of water based photovoltaic/thermal (PV/T) system with and without phase change material (PCM). Solar Energy, 155: 1104-1120. https://doi.org/10.1016/j.solener.2017.07.040

[6] Al-Waeli, A.H., Sopian, K., Kazem, H.A., Chaichan, M.T. (2017). Photovoltaic/Thermal (PV/T) systems: Status and future prospects. Renewable and Sustainable Energy Reviews, 77: 109-130. https://doi.org/10.1016/j.rser.2017.03.126

[7] Yang, X., Sun, L., Yuan, Y., Zhao, X., Cao, X. (2018). Experimental investigation on performance comparison of PV/T-PCM system and PV/T system. Renewable energy, 119: 152-159. https://doi.org/10.1016/j.renene.2017.11.094

[8] Smyth, M., Pugsley, A., Hanna, G., Zacharopoulos, A., Mondol, J., Besheer, A., Savvides, A. (2019). Experimental performance characterisation of a hybrid photovoltaic/solar thermal façade module compared to a flat integrated collector storage solar water heater module. Renewable Energy, 137:

137-143. https://doi.org/10.1016/j.renene.2018.04.017

[9] Browne, M.C., Quigley, D., Hard, H.R., Gilligan, S., Ribeiro, N.C., Almeida, N., McCormack, S.J. (2016). Assessing the thermal performance of phase change material in a photovoltaic/thermal system. Energy Procedia, 91: 113-121. https://doi.org/10.1016/j.egypro.2016.06.184

[10] Browne, M.C., Norton, B., McCormack, S.J. (2015). Phase change materials for photovoltaic thermal management. Renewable and Sustainable Energy Reviews, 47: 762-782. https://doi.org/10.1016/j.rser.2015.03.050

[11] Venkatesh, R., Vijayan, V. (2017). Performance Evaluation of Multipurpose Solar Heating System. Mechanics and Mechanical Engineering, 20(4): 359-370

[12] Isravel, R.S., Raja, M., Saravanan, S., Vijayan, V. (2020). Thermal augmentation in parabolic trough collector solar water heater using rings attached twisted tapes. Materials Today: Proceedings, 21(1): 497-499. https://doi.org/10.1016/j.matpr.2019.05.375

[13] kumar, R.R., Suthahar, S.T., Sakthivel, C., Vijayan, V., Yokeshwaran, R. (2020). Performance analysis of solar water heater by using TiO2 nanofluids. Materials Today: Proceedings, 21(1): 817-819. https://doi.org/10.1016/j.matpr.2019.07.251

[14] Stopnik, R., Stritih, U. (2016). Increasing the efficiency of PV panel with the use of PCM. Renewable Energy, 97: 671-679. https://doi.org/10.1016/j.renene.2016.06.011

[15] Browne, M.C., Norton, B., McCormack, S.J. (2016). Heat retention of a photovoltaic/thermal collector with PCM. Solar Energy, 133: 533-548. https://doi.org/10.1016/j.solener.2016.04.024

[16] Browne, M.C., Lawlor, K., Kelly, A., Norton, B., Mc Cormack, S.J. (2015). Indoor characterisation of a photovoltaic/thermal phase change material system. Energy Procedia, 70: 163-171. https://doi.org/10.1016/j.egypro.2015.02.112

[17] Zhou, D., Eames, P. (2017). A study of a eutectic salt of lithium nitrate and sodium chloride (87-13\%) for latent heat storage. Solar Energy Materials and Solar Cells, 167: 157-161. https://doi.org/10.1016/j.solmat.2017.04.016 